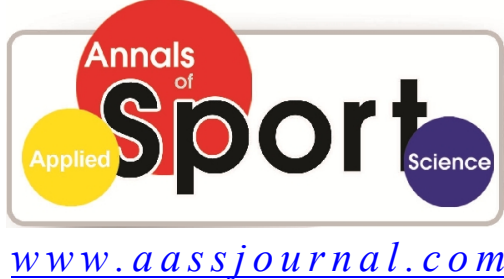

ISSN (Online): $2322-4479$

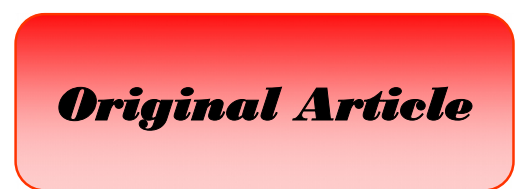

Received: $28 / 04 / 2014$

Accepted: 25/06/2014

\title{
Green Marketing and Its Impacts on Consumer Behavior in Sports Shops
}

\section{Javad Shahlaee Bagheri*}

- Department of Sport Management, Faculty of physical education and sport sciences, Allameh Tabataba'i University, Tehran, Iran.

\begin{abstract}
The aim of this study was investigation of green marketing and its impacts on consumer behavior in sports shops in East Azerbaijan province of Iran. The present study is functionalized by objectives and done by field. The study statistical society was sports shops in East Azerbaijan and 210 samples were chosen randomly according to Morgan sampling method and 196 questionnaires were collected finally. The author-prepared questionnaire's validity was approved by some experts in sport management and marketing. Field and the reliability were assessed by pilot study using Chronbach's Alpha $(\alpha=819 \%)$ which showed that the tool was reliable. The questionnaire had 30 items rated by Lakers scale. Questionnaire introduction contained demographic pieces information of age, income and education degree. Results shows that a significant relationship between green products features, green promotion, green pricing and green distributing with consumer green behavior; and education, income, and age, but not marital status, gender had a moderating effect on consumer green sports behavior.
\end{abstract}

Key Words: Green Marketing, Green Consumer, Product Characteristics, Environmental Knowledge, Price, Green Promotion.

Corresponding Author:

Javad Shahlaee Bagheri

E-mail: javadshahlaee@gmail.com 


\section{INTRODUCTION}

Green Marketing is the marketing of products which are presumed to be environmentally safe. Thus, green marketing incorporates a broad range of activities, including product modification, changes to the production process, packaging changes, as well as modifying advertising. Yet defining green marketing is not a simple task where several meanings intersect and contradict with each other, an example of this will be the existence of varying social, environmental and retail definitions attached to this term. Other similar terms used are Environmental Marketing and Ecological Marketing. Different authors have given different definitions of green marketing. According to the American Marketing Association, there are 3 ways to define Green Marketing (1):

- Retailing Definition: The marketing of products that are presumed to be environmentally safe.

- Socially Marketing Definition: The development and marketing of products designed to minimize the negative effects on the physical environment or to improve its quality.

- Environmental Definition: The effort by organization to produce, promote, package and reclaim products in a manner which is sensitive or responsive to ecological concerns.

Ottman (1998) defines green product as a product in which typically nontoxic, made from recycled materials, or minimally packaged (2). Mishra and Sharma (2010) characterizes green product based on a few features, including original growth, recyclable/reusable, containing natural ingredients, containing recycled content, not polluting environment, containing approved chemical and not being tested on animals (3).

Green marketing refers to the businessman of environmental protection concepts as his business philosophy, with green culture as his concept of value, so as to eliminate or reduce the damage of the earth's ecosystem for center in order to meet consumers' green consumption as a starting point, and gain profit and development and implementation of the marketing strategy. Merchants in choosing merchandise, want to reduce choose commodity; unfavorable to environmental protection Considering the design product packaging, try to reduce the remnants of commodity use environmental impact; In merchandise sales process, will guide consumers in use and consumer goods to minimize the environmental impact of; In after-sales service process, want to save resources and less pollution for its service orientation (4).

Green purchase intention is conceptualized as the probability and willingness of a person to give preference to products having eco-friendly features over other traditional products in their purchase considerations (5). Chan (2001) defines green purchase as a specific kind of ecofriendly behavior that consumers perform to express their concern to environment (6). Since the consumer intention has been used as a proxy for actual behavior, this study would like to further discuss the determinants of green purchase intention. The identified determinants of green purchase intention include environmental knowledge, environmental attitude, government initiative, peer pressure, and eco-label.

Lee (2008) defines environmental attitude as the individuals' value judgments of environmental protection which taps the individuals' cognitive assessment of the value of the environmental protection (7).

According to Chen and Chang (2012) these green marketing efforts enhance consumer's purchase intentions. Companies need to focus on reducing the green perceived risk by giving trustworthy 
information so that it helps build the trust with the customers, improve the green perceived value and enhance the purchase intentions about buying a green product (8). Besides, consumers propose that environmental advertisements are more effective in enhancing their knowledge about green products and help make informed decisions (9). Therefore, environmental advertisement can help enhance motivation towards buying green products. Moreover, according to Hartmann and Ibanez (2006) consumers will more likely buy a green product having ecological packaging provided that they meet cost benefit analysis (10). Sustainability is also demanded from industrial suppliers, and exporters are under pressure for supplying eco-packed products (11). Companies have been faced with a new challenge in production since green customer was proposed and they have move gradually towards green marketing. This term, i.e., green marketing refers to planning, development and promotion of goods or services which satisfy consumers' needs without a negative effect on the environment and by means of natural raw materials and saving the energy (12).

Certifications of independent agencies on one hand can help prevent the deception of customers and also decrease skeptical feelings in connection with environmental claims. On the other hand, they make it easier for the consumer to identify the environmentally friendly product because in our world products are so complicated that we don't have enough knowledge to decide on their level of greenness. Not only can product ingredients/product features be important in this decision but the production procedure, technologies used by the company as well and customers can also get information on these things rarely, or searching for this data would mean too much energy from their side. Therefore, certification is a very brief summary of all green features of the product and it is easy to be understood (13).

Kaufmann, Panni, and Orphanidou (2012) reported age, gender, income level, education degree, ethnicity, and occupation are demographic variables and environmental knowledge, and environmental awareness are independent variables. According to the results of the analysis, environmental awareness, green product features, green promotion activities and green price affect green purchasing behaviors of the consumers in a positive way (14). Besides, demographic characteristics (age, income education, gender and marital status) have moderate effect on this model (15).

The results of the study indicated that environmental knowledge, environmental attitude, governmental initiative and peer pressure have significant influences on green purchase intention of Malaysian consumer. In contrast, eco-label failed to show significant relationship with green purchase intention (16).

Akehurst, Afonso, and Gonçalves (2012) re-examined the determinants of Ecologically Conscious Consumer Behavior (ECCB) through building consumer profiles (sociodemographic and psychographic components). The study also explored about the determinant of effective green purchase behavior (GPB) through analyzing ECCB and Green Purchase Intention (GPI) from previous studies. For this purpose, researchers conducted an online survey and concluded that psychographic variables were more important in characterizing ECCB than demographic ones, and there was a positive relationship between ECCB and GPI. Also, ECCB had more impact on GPB than GPI (9).

Chen and Chang (2012) developed a framework to look at the effects of green perceived value and green perceived risk on green purchase intention as well as to find the role of green trust on these aforementioned variables (8). The study 
showed a positive influence of green perceived value on green trust and green purchase intention, whereas green perceived risk has a negative influence on both of them. Moreover, the study showed that green perceived intention and its antecedent green perceived value and green perceived risk are partially influenced by green trust (8). Which one concluded that resources should be invested in increasing the green perceived value and minimizing green perceived risk that will lead to higher trust and green purchase intention?

Rahbar and Wahid (2011) investigated the effects of green marketing tools (eco labels, eco brand, environmental advertisement and trust in eco label and eco brand) on actual consumer purchase behavior (17). Findings of the study showed that trust in eco label and eco brand were significantly related. Whereas relationship between knowledge about eco labels and the effect on consumer purchase behavior was not significant. Moreover, environmental advertisement, another dimension of green marketing was not found to be significant (17). Akehurst, Afonso, and Gonçalves (2012) studied the impact of sociodemographic and psychographic variables on ecological conscious consumers. The study concluded with psychographic variables as more convincing towards affecting the behavior (9). The results showed that companies need to increase their communication with the customers on going green, and that attributes like price and quality are more important than environmental responsibility (18).

The results indicated that green marketing has a significant effect on social responsibility and product image. The effect of green marketing on corporate reputation is not significant and three factors of corporate image have a direct effect on intention to purchase. Given the indirect effects among the variables, green marketing has a significant effect on intention to purchase (19).

Findings of the research have been explored, demonstrating that all the adopted variables namely; consumer belief, social influence, environmental attitude, and perceived quality of green product significantly and positively influence the green purchasing intention of young Malaysian consumers and are considered significant predictors. Moreover, limitations and contributions of the study have been discussed. Finally, the marketing implications as well as recommendations support the importance of the adopted variables as having a significant impact on the purchasing intention of green products among young Malaysian consumers (20). Results show a significant relationship between environmental knowledge, green product features enhanced green, green pricing and green certificates, with consumer green behavior (21).

\section{MATERIALS AND METHODS}

The present study was conducted using descriptive-field method.

Participants. The study sample was selected among sports shops in East Azerbaijan in Iran 2014. The study samples were determined using a table of sample volumes of 196. The risk of loss or altered in subjects with incomplete questionnaires, 210 questionnaires were collected randomly distributing.

Instruments. The research tool was questionnaire prepared by the authors and its validity was approved by some experts in management field and also its reliability was assessed after piloting the questionnaire in a small group and using Chronbach's Alpha $(\alpha=819 \%)$ which showed that the tool was reliable. The questionnaire has of 30 items rated as a five-item Likert scale [From 1 (very low) to 5 (too much high)]. Questionnaire introduction contained 
demographic information and subjects including age, income and degree of education.

Statistical Analysis. Testing of the hypotheses in this section was analyzed through inferential statistics and it was tried to find a suitable response to research questions given for confirmation or rejection of hypotheses. First, correlation among the variables was studied and one way-ANOVA test was used to demonstrate the effects of the moderating role of age, income, education and marital status and independent t-test was used for gender.

\section{RESULTS}

Demographical property of the consumers participating in the research is showed in Table 1.

Table 1. Demographical Properties of the Consumers Participating in the Research

\begin{tabular}{|c|c|c|c|}
\hline Factor & Category & $\mathrm{N}$ & $\%$ \\
\hline \multirow{4}{*}{ Age } & $20-29$ & 93 & 47.4 \\
\hline & $30-39$ & 43 & 21.9 \\
\hline & $40-49$ & 32 & 16.4 \\
\hline & $>50$ & 28 & 14.3 \\
\hline \multirow{2}{*}{ Gender } & Male & 126 & 64.3 \\
\hline & Female & 70 & 35.7 \\
\hline \multirow{4}{*}{ Education } & Elementary school & 28 & 14.3 \\
\hline & High school & 44 & 22.4 \\
\hline & Bachelor & 88 & 44.9 \\
\hline & $\mathrm{PhD}$ & 36 & 18.4 \\
\hline \multirow{3}{*}{ Marital Status } & Unmarried & 62 & 31.6 \\
\hline & Married & 50 & 25.5 \\
\hline & Married and have children & 84 & 42.9 \\
\hline \multirow{3}{*}{ Income } & $0-300 \$$ & 72 & 36.7 \\
\hline & $300-500 \$$ & 77 & 39.3 \\
\hline & $500 \$-$ & 47 & 34 \\
\hline & otal & 196 & 100 \\
\hline
\end{tabular}

Spearman correlation test (Table 2) $\mathrm{p}=0.001), \quad$ green promotions $\quad(\mathrm{r}=0.460$, showed that there is a significant and $\mathrm{p}=0.001)$, green distribution $(\mathrm{r}=0.666$, positive relationship between green purchasing behavior with green product $\mathrm{p}=0.001)$, and green certification $(\mathrm{r}=0.481$, $(\mathrm{r}=0.551, \mathrm{p}=0.001)$, green prices $(\mathrm{r}=0.347$, $\mathrm{p}=0.001)$.

Table 2. Spearman correlation test of green purchasing behavior with green marketing dimensions

\begin{tabular}{c|c|cccc}
\hline & $\begin{array}{c}\text { Green } \\
\text { Product }\end{array}$ & $\begin{array}{c}\text { Green } \\
\text { Prices }\end{array}$ & $\begin{array}{c}\text { Green } \\
\text { Promotions }\end{array}$ & $\begin{array}{c}\text { Green } \\
\text { Distribution }\end{array}$ & $\begin{array}{c}\text { Green } \\
\text { Certification }\end{array}$ \\
\hline $\begin{array}{c}\text { Green Purchasing } \\
\text { Behavior }\end{array}$ & 0.551 & 0.347 & 0.460 & 0.666 & 0.481 \\
\cline { 2 - 6 } & $0.001^{* *}$ & $0.001^{* *}$ & $0.001^{* *}$ & $0.001^{* *}$ & $0.001^{* *}$ \\
\hline
\end{tabular}

ANOVA test (Table 3 ) revealed that there is significant impact of age $(\mathrm{F}=31.188$, $\mathrm{p}=0.001)$, education $(\mathrm{F}=23.981, \mathrm{p}=0.001)$, and income on green purchasing behavior
$(F=7.371, \quad p=0.001)$, but the impact of marital status on green purchasing behavior was not significant $(\mathrm{F}=3.200, \mathrm{p}=0.43)$. 
Table 3. ANOVA test of impact of demographic properties on green purchasing behavior

\begin{tabular}{ccc} 
Demographic Properties & $\mathrm{F}$ & $\mathrm{p}$ \\
\hline Age & 31.188 & $0.001^{* *}$ \\
\hline Education & 23.981 & $0.001^{* *}$ \\
\hline Marital Status & 3.200 & $.0430^{* *}$ \\
\hline Income & 7.371 & $0.001^{* *}$ \\
\hline
\end{tabular}

$* *$ : significant at the $\mathrm{p}<0.01$

Also t-test showed that the exposure level of green purchasing behavior from green marketing for female and male consumer wasn't statistically different $(\mathrm{t}=-2.29$, $\mathrm{p}=0.23$ ). Gender hadn't a moderating effect (Table 4).

Table 4. Independent t-test of impact of demographic properties on green purchasing behavior

Variable

Gender

$-2.29$

0.23

\section{DISCUSSION and CONCLUSION}

Results shows a significant relationship between green products features, green promotion, green pricing and green distributing with consumer green behavior. This favors Hajieqrari (2014) research result, which also showed a significant relationship between environmental knowledge, green product features enhanced green, green pricing and green certificates, with consumer green behavior (21), and this favors Boztepe (2012) results that show environmental awareness, green product features, green promotion activities and green price affect green purchasing behaviors of the consumers in a positive way (15).

Findings show a significant and positive relationship between green certification and green purchasing behavior this in direction of Majláth (2012) result that show green certification make it easier for the consumer to identify the environmentally friendly product (13).

The results showed that education, income, and age but not marital status, gender has a moderating effect on consumer green sports behavior. This is both in line and inconsistent with Boztepe (2012) results that show demographic characteristics (age, income education, gender and marital status) have moderate effect on green purchase behavior and This is both in line and inconsistent with Kaufmann, Panni, and Orphanidou (2012) research results that showed that age, gender, income level, education level, ethnicity, and occupation are demographic variables and environmental knowledge, environmental awareness are independent variables (14).

Analysis of research findings on demographic factors show:

- Age has a moderating effect on this model. According to the observed mean, when age increases, the amount of green purchase behavior variable becomes less.

- Education has a moderating effect on this model. According to the observed mean when education increases, the amount of green purchase behavior variable also increases.

- Income has a moderating effect on this model. According to the observed mean, when income increases, the amount of green purchase behavior variable becomes less.

- Marital status and gender hasn't a moderating effect on this model.

\section{REFFRENCES}

1. Laxhminarayan D, editor. Green Marketing and its impact in Global Business. International Conference on Technology and Business Management (ICTBM-12); 2012; Dubai: University of Wollongong.

2. Ottman JA. Green Marketing: Opportunity for Innovation. 2nd ed: NTC Business Books; 1998. 270 p.

3. Mishra P, Sharma P. Green marketing in India: Emerging opportunities and challenges. Journal of Engineering, Science and Management Education. 2010;3(1):9-14. 
4. Zhi-bin C. Green Marketing and Green of SME Logistics Management. 2012 International Conference on Economic Management and Engineering Technology: Lecture Notes in Information Technology2012. p. 55-9.

5. Rashid NRNA. Awareness of eco-label in Malaysia's green marketing initiative. International Journal of Business and Management. 2009;4(8):132-41.

6. Chan RYK. Determinants of Chinese consumers' green purchase behavior. Psychology and Marketing. 2001;18(4):389-413.

7. Lee K. Opportunities for green marketing: young consumers. Marketing Intelligence \& Planning. 2008;26(6):573-86.

8. Chen Y-S, Chang C-H. Enhance green purchase intentions: The roles of green perceived value, green perceived risk, and green trust. Management Decision. 2012;50(3):502-20.

9. Akehurst G, Afonso C, Gonçalves HM. Re-examining green purchase behaviour and the green consumer profile: new evidences. Management Decision. 2012;50(5):972-88.

10. Hartmann P, Ibanez VA. Green value added. Marketing Intelligence \& Planning. 2006;24(7):673-80.

11. Saxena RP, Khandelwal PK. Greening of industries for sustainable growth: An exploratory study on durable, non-durable and services industries. International Journal of Social Economics. 2012;39(8):551-86.

12. Grant J. Green marketing. Strategic Direction. 2008;24(6):25-7.

13. Majláth M. Actual Questions of Green Marketing. 10th International Conference on Mangement, Enterprise and Benchmarking (MEB 2012); Budapest, Hungary: Óbuda University, Keleti Faculty of Business and Management; 2012. p. 255-62.

14. Kaufmann HR, Panni M, Orphanidou Y. Factors affecting consumers' green purchasing behavior: an integrated conceptual framework. Amfiteatru Economic. 2012;15(31):50-69.

15. Boztepe A. Green marketing and its impact on consumer buying behavior. European Journal of Economic and Political Studies. 2012;5(1):5-21.

16. Mei OJ, Ling KC, Piew TH. The antecedents of green purchase intention among Malaysian consumers. Asian Social Science. 2012;8(13):246-63.

17. Rahbar E, Wahid NA. Investigation of green marketing tools' effect on consumers' purchase behavior. Business Strategy Series. 2011;12(2):73-83.

18. Bukhari SS. Green Marketing and its impact on consumer behavior. European Journal of Business and Management. 2011;3(4):375-83.

19. Haery FA, Dehaghi MR, Yazdani A. Effect of Green Marketing on Consumer Purchase Intentions With Regard to the Company's Image as a Mediator in the Retail Setting Case study: The Customers of Naghshe-e Jahan Sugar Company. International Journal of Academic Research in Business and Social Sciences. 2013;3(11):442-52.

20. Iravani MR, Sadeghi Zadeh M, Forozia A, Shafaruddin N, Mahroeian H. Study of Factors Affecting Young Consumers to Choose Green Products. Journal of Basic and Applied Scientific Research. 2012;2(6):5534-44.

21. Hajieqrari A, editor. Green marketing and its impact on consumer behavior in selected sports shops in East Azerbaijan (Tabriz, Marand, Maragheh). First National Conference of Sports Management Application; 2014; Garmsar, Iran: Garmsar Branch, Payam Noor University. 
تازههاى علوم كاربردى ورزش

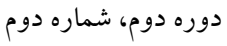

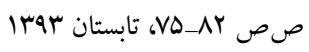

مقاله اصيل

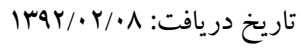

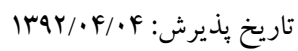

\section{بازاريابى سبز و اثر آن بر رفتار مشترى در مغازههاى ورزشى جواد شهرلايى باقرى}

- استاديار گروه مديريت ورزشى، دانشكده تربيتبدنى و علوم ورزشى، دانشگاه علامه طباطبايى، تهران، ايران.

جكيده

هدف از تحقيق حاضر بررسى بازاريابى سبز و اثر آن بر رفتار مشترى در مغازهاى ورزشى آذربايجان شرقى بود. جامعه آمارى تحقيق مغازههاى

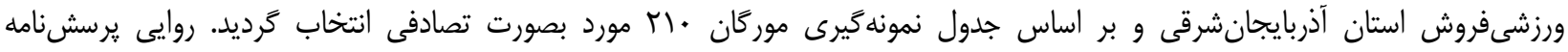

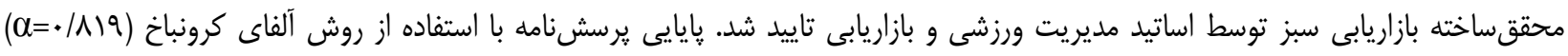

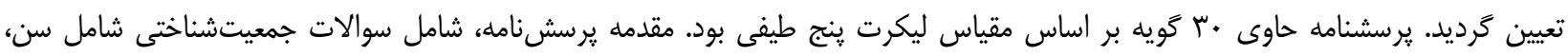

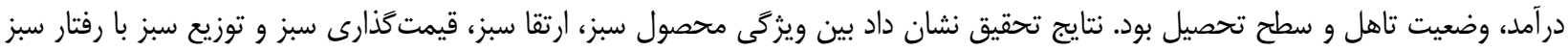

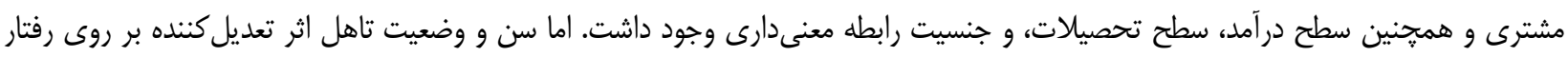
سبز مشترى نداشت. وازگَان كليدى: بازاريابى سبز، مشترى سبز، ويزَى محصول، دانش سبز، قيمت، ارتقا سبز. 